\title{
MENGUJI 5 MACAM PUPUK DAUN DENGAN MENGUKUR KADAR GULA TOTAL BIJI JAGUNG MANIS (Zea mays saccharata )
}

\author{
SURTINAH \\ Staf Pengajar Fakultas Pertanian Universitas Lancang kuning \\ Jurusan Budidaya Pertanian \\ Jl. D.I. Panjaitan Km. 8 Rumbai Telp. (0761)52439
}

\begin{abstract}
ABSTRAK
Tujuan penelitian ini adalah untuk mendapatkan pupuk daun yang paling cocok untuk memperbaiki kualitas jagung manis yang di tanam di Kota pekanbaru. Penelitian ini dilaksanakan secara eksperimen dengan menguji 5 macam pupuk daun sebagai perlakuan, dan kontrol ( tanpa pupuk daun ). Pupuk daun yang dimaksud adalah Bayfolan; Gandasil B; pupuk cair NR; pupuk SNN; pupuk Super Bionik, dan tanpa pupuk. Rancangan lingkungan yang digunakan adalah Rancangan acak Lengkap dengan 4 kali ulangan. Parameter yang diamati hanya Kadar gula total biji jagung manis ( Zea mays saccharata). Hasil penelitian menunjukkan bahwa ke lima macam pupuk daun yang digunakan tidak dapat memningkatkan kadar gula total biji jagung manis tersebut.
\end{abstract}

Kata Kunci : Kadar gula, Bayfolan, Gandasil B, Pupuk NR, Pupuk SNN, Pupuk Super Bionik, Kualitas, Jagung Manis

\section{PENDAHULUAN}

\begin{tabular}{|c|c|}
\hline \multirow{2}{*}{\multicolumn{2}{|c|}{$\begin{array}{l}\text { Produksi jagung } \text { manis } \\
\text { Nasional dari tahun ke tahun } \\
\text { mengalami penurunan. }\end{array}$}} \\
\hline & \\
\hline \multirow{5}{*}{$\begin{array}{l}\text { Produksi jagung manis } \\
\text { Nasional dari tahun ke tahun } \\
\text { mengalami penurunan. Diakhir } \\
\text { tahun 2000 yaitu } 9.344 .926 \text { ton } \\
\text { sedang diakhir tahun } 2002 \text { yaitu } \\
9.277 .258 \text { ton ( Marzuki, 2002 ). } \\
\text { Demikian juga untuk daerah Riau } \\
\text { mengalami penurunan produksi }\end{array}$} & Pekanbaru merupakan s \\
\hline & budidaya \\
\hline & prospek cerah, namun kendala ya \\
\hline & dihadapi adalah mutu jagung ma \\
\hline & $m$ \\
\hline tahun & elum diuji, sehingga mutu \\
\hline luksinya 38.588 ton, & lum dapat diba \\
\hline tahun 2001 produksi mencapai & $\begin{array}{l}\text { mutu orj yang } \\
\text { vano diounakan }\end{array}$ \\
\hline Berdasarkan survey & yang digunakan. \\
\hline jang telah dilakukan pada beberapa & Jagung manis sesu \\
\hline agang dan pebjual di pasar, & namanya memiliki kada \\
\hline eramaian lainnya diperc & ukup tinggi, sehingga ra \\
\hline nasi bahwa kebutuhan & $\mathrm{s}$ dari jagung $\mathrm{b}$ \\
\hline anıs setıap harınya mencapa & juga varitas lokal yang \\
\hline 10.000 tongkol pada hari - hari & kadar gula $9-11 \%$, sedangk \\
\hline & aritas Hybrid Super Sv \\
\hline 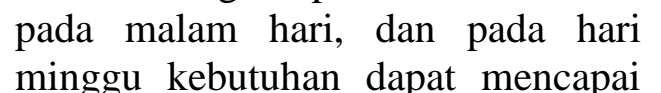 & miliki kadar gula 1 \\
\hline
\end{tabular}


Pasar jagung manis yang terbuka lebar memberikan peluang bisnis yang sangat diminati oleh masyarakat tani, namun kendala mutu menjadikan harga jagung manis ditingkat petani menjadi anjlok tidak seperti petani-petani jagung manis di daerah sentra produksi lainnya.

Permintaan pasar yang meningkat bila diikuti dengan mutu produksi yang baik maka akan meningkatkan penghasilan dengan meningkatnya harga jual. Mutu produksi yang baik akan diperoleh bila teknik budidayanya sesuai dengan yang dikehendaki oleh tanaman tersebut.

$$
\text { Hasil jagung manis }
$$

ditentukan oleh bobot segat per tanaman, karena jagung manis dikonsumsi dalam bentuk tongkol segar. Semakin tinggi bobot tongkol segar per tanaman, maka akan semakin tinggi pula hasilnya. Kualitas jagung manis ditentukan oleh adanya kandungan gula yang dikandung oleh biji jagung manis.

Kualitas jagung manis dipengaruhi oleh faktor genetik dan lingkungan. Faktor lingkungan yang mempengaruhi pertumbuhan dan produksi jagung manis adalah pemupukan ( Muis, 2002 ). Jagung manis lebih banyak membutuhkan $\mathrm{N}$ dibanding dengan jagung varitas lainnya. ( Naviosade ( 2002 ) melaporkan bahwa pemupukan berpengaruh terhadap jumlah daun tanaman jagung manis, sehingga secara tidak langsung akan berpengaruh terhadap kualitas jagung manis tersebut. Sementara itu Santoso dkk. ( 2002 ) melaporkan bahwa pupuk Urea yang diberikan ke tanah akan diurai menjadi $\mathrm{NH}^{+}{ }_{4}$ dan $\mathrm{CO}_{2}$ oleh enzim Urease, dan selanjutnya diambil oleh akar dan digunakan untuk memenuhi kebutuhan tanaman.

Pupuk dapat diberikan melalui daun, karena proses penyerapan unsur haranya berjalan lebih cepat dibanding pupuk yang diberikan lewat akar. ( Prajnanta, 2002 ) menyatakan bahwa penyemprotan pupuk melalui daun, akan

meningkatkan tekanan turgor. Tekanan turgor meningkat mengakibatkan sel-sel penjaga dari stomata menjadi penuh air dan mengakibatkan stomata terbuka, sehingga penyerapan larutan yang mengandung hara akan lebih mudah. Lingga dan marsono ( 2001 ) menyimpulkan pemberian pupuk melaui daun dipandang lebih berhasil dibandingkan dengan pemupukan lewat akar.

Sutejo ( 2002, dalam Surtinah 2006 ), menjelaskan bahwa pupuk daun mampu meningkatkan kegiatan fotosintesis dan daya angkut unsur hara dari dalam tanah ke dalam jaringan, mengurangi kehilangan Nitrogen dari jaringan daun, meningkatkan pembentukan karbohidrat, lemak dan protein, serta meningkatkan potensi hasil tanaman.

Pupuk daun mengandung unsur makro dan mikro, sehingga kebutuhan tanaman akan unru-unsur tersebut dapat terpenuhi. Pupuk daun Bayfolan merupakan pupuk daun lengkap dengan kandungan $\mathrm{N}$ $11 \%, \mathrm{P}_{2} \mathrm{O}_{5} 8 \%, \mathrm{~K}_{2} \mathrm{O} 6 \%$, dan unsur-unsur mikro lainnya seperti $\mathrm{Fe}$, $\mathrm{B}, \mathrm{Co}, \mathrm{Mn}, \mathrm{Zn}$, dan $\mathrm{Cu}$ ( Anonimus, 1985 ).

Pupuk daun Gandasil B mengandung N $6 \%, \mathrm{P} 20 \%, \mathrm{~K} 30$ $\%$, dan $\mathrm{Mg} 3 \%$, unsur mikro yang terkandung di dalamnya adalah $\mathrm{Mn}$, $\mathrm{B}, \mathrm{Cu}, \mathrm{Co}$, dan $\mathrm{Zn}$, dengan dosis $2 \mathrm{~g} /$ 1 air dan diberikan empat kali dapat 
memperpenjang umur panen, meningkatkan bobot kering tanaman, meningkatkan bobot segar buah, dan menambah tebal daging buah ( Surtinah, 2004 ).

Pupuk Cair NR mengandung $\mathrm{N} 8800$ ppm, $\mathrm{P}_{2} \mathrm{O}_{5} 14.100$ ppm, $\mathrm{K}_{2} \mathrm{O}$ 25.600 ppm, $\mathrm{CaO} 3.600$ ppm, $\mathrm{MgO}$ 2.600 ppm, S 6300 ppm, Fe 1.100 ppm, Mn 20 ppm, Cu 16 ppm, Mo 30 ppm, B 100 ppm, Zn 50 ppm ( Anonimous, 2002 ).

Pupuk SNN mengandung $\mathrm{N}$ $25 \%$, P $25 \% \mathrm{~K} 25 \%$, MG, S, Ca, $\mathrm{Fe}, \mathrm{Na}, \mathrm{Zn}, \mathrm{Cu}, \mathrm{Mn}, \mathrm{B}$, dan $\mathrm{Cl}$, dosis anjuran untuk jagung manis $2 \mathrm{cc} / 1$ air dengan interval 10, 20, dan 30 hari setelah tanam ( Indmira, 2004 ).

Pupuk cair Super Bionik mengandung $\mathrm{C}$ - Organik $0,3 \%, \mathrm{~N}$ $8.15 \%, \mathrm{P}_{2} \mathrm{O}_{5} 1,25 \%, \mathrm{~K}_{2} \mathrm{O} 5,05 \%$, $\mathrm{SO}_{4} 0,2 \%, \mathrm{MgO} 0,03 \%, \mathrm{CaO} 0,07$ $\%, \mathrm{C} / \mathrm{N}$ rasio $0,71, \mathrm{Fe} 42,25 \mathrm{ppm}, \mathrm{Cu}$ 0,8 ppm, Zn 22,41 ppm, Cl 0,27 ppm, B 0,57 ppm, Mo 0,2 ppm, Mn 2,27 ppm, asam-asam amino, 3 macam hormon ( Cytokinin, IAA, dan Giberelin ), pada konsentrasi 1,9 cc/l air dilaporkan menghasilkan jumlah daun tanaman selada yang paling optimal ( Triwaluyo, 2006 ).

Tujuan penelitian ini adalah mendapatkan pupuk daun yang paling cocok untuk memperbaiki kualitas jagung manis yang di tanam di Kota pekanbaru.

\section{METODE PENELITIAN}

Penelitian dilaksanakan
secara eksperimen dalam pola
Rancangan Acak lengkap, yang
terdiri dari 6 perlakuan dan 4 kali
ulangan sehingga diperoleh 24 unit
percobaan.

Perlakuan-perlakuan tersebut ialah :

1. Kontrol

2. Pupuk Bayfolan ( $2 \mathrm{cc} / 1$ air )

3. Pupuk Gnadasil B ( 2 g / 1 air )
4. Pupuk NR ( $4 \mathrm{cc} / 1$ air )

5. pupuk SNN ( $2 \mathrm{cc} / 1$ air )

6. pupuk Super Bionik ( $2 \mathrm{cc} / 1$ air )

Model Sidik Ragam yang digunakan adalah :

$$
Y_{i j}=M+P_{i}+E_{i j}
$$

Surtinah, 2003 )

Dilanjutkan dengan uji DNMRT taraf $5 \%$.

Pupuk yang akan diuji diberikan sesuai dengan dosis atau konsentrasi anjuran, dan diberikan sebanyak tiga kali yaitu pada saat tanaman berumur 15 hari, 30 hari, dan 45 hari setelah tanam. Cara pemberiannya dengan menyemprotkan ke seluruh bagian tanaman, unit percobaan kontrol juga mendapatkan semprotan air saja tanpa zat terlarut.

Tanah diolah dua kali, kemudian dibuat Plot percobaan yang berukuran $150 \times 100 \mathrm{~cm}$, jarak antar plot $50 \mathrm{~cm}$. Setiap plot diberi pupuk kandang sebanyak 1,5 kg yang dicampur rata pada saat pengolahan tanah kedua. Selanjutnya pemasangan label sesuai dengan hasil pengacakan perlakuan. Jarak tanam yang digunakan adalah $20 \times 75 \mathrm{~cm}$, setiap plot terdapat 10 tanaman, dan 4 tanaman dijadikan tanaman sampel. Setiap lubang tanam diisi dua butir benih dan dijarangkan pada umur 10 hari setelah tanam, sehingga tertinggal hanya 1 tanaman tiap lubang tanam.

Pupuk dasar yang diberikan, selain pupuk kandang adalah pupuk NPK sebanyak $10 \mathrm{~g} /$ tanaman yang diberikan bersamaan pada waktu tanam, dan diberikan dengan jarak 5 cm dari tanaman.

Pemeliharaan tanaman meliputi; penyiraman yang dilakukan setiap hari, pencegahan hama dan penyakit dengan menggukan Decis 2.5 EC 92 cc/l air ), dan Dithane M- 
45 ( 2 cc/l air ) diberikan pada tanaman yang berumur 4 dan 8 minggu setelah tanam. Penyiangan gulma bersamaan dengan pembumbunan yaitu pada umur 15 hari setelah tanam.

Parameter pengamatan adalah kadar gula total biji, yang diamati pada akhir penelitian. pengukuran kadar gula menggunakan hand refraktometer dengan cara

\section{HASIL PENELITIAN}

Hasil sidik ragam menunjukkan bahwa pupuk daun yang diuji memberikan pengaruh tidak nyata terhadap kadar gula total biji jagung manis.

\begin{tabular}{|l|c|}
\hline $\begin{array}{l}\text { Perlakuan } \\
\text { Pupuk }\end{array}$ & $\begin{array}{l}\text { Kadar gula } \\
\text { total } \\
\text { (\% brix })\end{array}$ \\
\hline Kontrol & 15.00 \\
Bayfolan & 15.00 \\
Gandasil B & 15.00 \\
NR & 15.37 \\
SNN & 15.00 \\
Super Bionik & 15.00 \\
\hline KK & $5.6 \%$ \\
\hline
\end{tabular}

Pada tabel tersebut terlihat pupuk daun sepertinya belum mampu untuk meningkatkan kadar gula total biji jagung manis, walaupun diketahui bahwa setiap pupuk daun memiliki kandungan unsur hara yang berbeda baik komposisinya, maupun senyawa tambahan yang dapat dihandalkan dalam memacu pertumbuhan tanaman. Tetapi kenyataannya hasil sidik ragam bertolak belakang degan fungsi yang sesungguhnya dari unsur-unsur yang terkandung pada pupuk tersebut. Hal ini diduga bahwa tanaman jagung manis kurang menghaluskan biji jagung, kemudian 1 tetes cairan ekstrak biji di letakkan di lensa alat tersebut dan ditutup, dan selanjutnya dilihat dengan cara meneropong alat tersebut, tetapkan skala hingga batas gelap dan terang pada alat sehingga dapat dibaca, angka yang dimaksud berada tepat pada garis batas hand refraktometer tersebut, dan kadar gula ditunjukkan dalam bentuk 5 brix.

respon terhadap pemupukan yang diberikan melalui daun.

Tabel di atas memperlihatkan hasil yang dianggap sama, kalaupun ada perbedaan, namun perbedaan itu sedikit sekali. Tanaman yang tidak diberi pupuk daun justru menunjukkan hasil yang baik dibandingkan tanaman yang diberi pupuk daun. Sehingga dapat disimpulkan bahwa untuk meningkatkan kadar gula biji jagung manis tidak perlu menggunakan pupuk daun.

Faktor-faktor yang dapat mempengaruhi penyerapan unsur hara melalui daun juga perlu dicermati. Penyerapan unsur hara melalui daun juga dipengaruhi oleh kondisi permukaan daun tanaman tersebut, bila daun tanaman berbulu, maka proses penyerapan juga akan tergannggu, begitu juga bila daun tanaman dilapisi lilin, maka proses penyerapan juga akan terganggu.

Daun tanaman jagung memiliki bulu, mungkin ini menjadi penyebab kurang efektifnya pupuk yang diberikan melalui daun tersebut. Hal ini bukan menjadi satusatunya kendala yang menyebabkan pupuk tidak masuk ke jaringan tanaman dengan sempurna, kesalahan juga bisa disebabkan 
karena kurang telitinya si peneliti dalam melaksanakan proses pemupukan.

Kendala lain yang dapat mempengaruhi proses masuknya larutan pupuk ke jaringan tanaman adalah kondisi iklim saat pelaksanaan pemupukan, dan waktu penyemprotan juga perlu diperhatikan. Dari hasil penelitian ini membuka peluang bagi peneliti lain untuk mengulangi penelitian ini dengan menggunakan metode yang sama dan dengan tujuan yang sama untuk membuktikan apakah memang benar tanaman jagung tidak respon terhadap pupuk yang diberikan melalui daun.

Kadar gula jagung manis varietas Super Sweet yang digunakan pada penelitian ini hanya mampu mencapai $15.37 \%$, sementara jagung manis varietas Super sweet ini memiliki kadar gula total antara 16 $18 \%$ ( Siswono, 2004 ). Artinya kadar gula jagung manis ini masih di bawah standard, kenapa hal ini bisa terjadi ? Banyak hal yang dapat menjelaskan tentang rendahnya kadar gula biji jagung manis varitas Super sweet ini, antara lain waktu panen yang tidak sesuai dengan kondisi lingkungan tempat penelitian, bisa menyebabkan kadar gula jadi menurun hal ini disebabkan terjadinya perubahan gula menjadi pati akibatnya biji jagung berkurang rasa manisnya. ( Nurhayati, 2002 ) melaporkan bahwa waktu panen yang tepat akan mempengaruhi kualitas jagung manis.

Faktor iklim yang dapat mempengaruhi rasa yang kurang manis dari biji jagung manis adalah curah hujan yang tinggi pada saat panen, ini juga dapat menyebabkan rasa biji menjadi kurang manis, karena kadar air biji pada saat masak fisiologis menjadi lebih tinggi. Hal ini ada hubungannya dengan proses asimilasi pada tanaman, pada kondisi yang kurang menguntungkan seperti itu, maka proses fotosintesis juga akan terganggu, karena intensitas cahaya yang dibutuhkan untuk fotolisis akan berkurang, sehingga asimilat yang dihasilkan juga berkurang.

\section{SIMPULAN}

Lima macam pupuk daun yang diberikan tidak mampu meningkatkan kadar gula total biji jagung manis varitas Super Sweet.

Kadar gula biji jagung manis yang dihasilkan dari penelitian ini belum memenuhi standard minimal yang diharapkan oleh varitas Super sweet.

\section{SARAN}

Penelitian ini perlu dilanjutkan dengan metode yang sama di waktu yang berbeda, untuk menjadi bahan perbandingan.

\section{DAFTAR PUSTAKA}

Anonimus 1985. Buletin Agronomi. Fakultas Pertanian Institut pertanian Bogor.Vol. VIII. No. 2. Bogor.

Anonimous 2002. Pupuk Cair Serba Guna NR. Buana Hijau Fertilizers SDN. BHD. Malysia.

Badan Pusat Statistik 2003. Survey Lapangan produksi jagung Manis. Pekanbaru.

Indmira 2004. Budidaya jagung lokal. Citra tani usaha. Yogyakarta.

Lingga dan Marsono, 2001. Petunjuk Penggunaan pupuk. Penebar swadaya. Jakarta. 
Marzuki, R. 2002. Bertanam jagung Manis. Penebar swadaya. Jakarta.

Muis 2002. Sugarcane Mosaic Virus Penyebab mosaic pada tanaman Jagung di Sulawesi. 21:2 J. Litbang Pertanian 64-68.

Naviosade 2002. Upaya peningkatan hasil dan Kualitas tanaman jagung Manis ( Zea mays sacharata ) Melaui Pupuk Kalium dan Pupuk Organik. 24:2 j. Agrivita: 136 - 144 .

Nurhayati 2002. pengaruh Takaran Pupuk Kandang dan Umur panen terhadap Hasil dan Kandungan Gula Jagung Manis. ( Skripsi ). Universitas terbuka.

Prajnanta, F. 2002. Melon, pemeliharaan secara Intensif, Kiat Sukses Beragribisnis. Penebar Swadaya. Jakarta.

Santoso, Bahri, dan Suminarti 2002. Respon Tanaman jagung Manis ( Zea mays sacharata ) Terhadap pemupukan Kalium dan Mengaplikasikan Pupuk Kandang sapi. XIII:4 J. Habitat: $212-220$.
Siswono 2004. Jagung Manis Rendah Lemak dan Kolesterol. Gizi Net.

Surtinah 2003. Perancangan Percobaan terapan, Untuk pertanian. ( Buku Ajar ). Jurusan Budidaya Pertanian. Universitas Lancang Kuning. Pekanbaru.

Surtinah 2004. Pengaruh Cekaman Air pada fase Tumbuh generatif dan Pemberian pupuk gandasil B Terhadap kualitas Buah melon ( Cucumis melo L ). XIX:3 J. Dinamika Pertanian: $325-335$.

Sutejo, S.S. 2002 di dalam Surtinah 2006. Peranan Plant catalyst 2006 Dalam meningkatkan Produksi Sawi ( Brassica juncea L ). 3 : 1 J. Ilmiah Pertanian: $6-16$.

Tri Waluyo, T. 2006. Pengaruh Pupuk Organik Super natural Nutrition pada Tanaman selada (Lactuca sativa, L ) di Lahan PMK. ( Skripsi ). Universitas lancang Kuning Pekanbaru. 